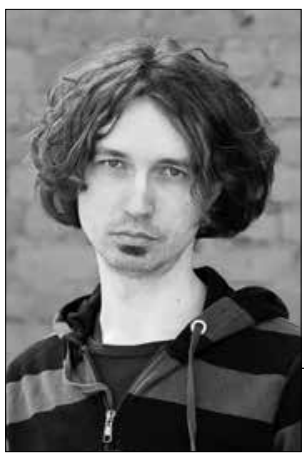

https://doi.org/10.24101/logos.2021.53

Gauta 20210826

\title{
AIVARAS STEPUKONIS
}

\section{SENEKA: APOLITINĖS MORALĖS PAMOKOS}

\author{
Seneca: Teachings Concerning Apolitical Morals
}

\author{
SUMMARY
}

The article discusses the place of politics and statesmanship in Seneca's moral philosophy as it is unfolded in his Ad Lucilium epistulae morales. For Seneca political office holds no intrinsic value. In principle, taking part in the affairs of state can be good and it can be evil. In actuality, however, the world of politics, for Seneca, is a dirty business. Political activities are fraught with so many ways to contract vice that everyone, who has chosen to pursue a life of virtue, should shun them as much as possible. Another reason why Seneca distances himself from active participation in the life of the state is his re-definition of what state, country, homeland really are. He turns away from a political order of human relations to a natural order of things. It is this all-encompassing world-order, driven by destiny, that becomes his true country and state.

\section{SANTRAUKA}

Straipsnyje remiantis Senekos Laiškais Lucilijui aptariama politikos ir valstybės tarnybos reikšmė dorovės filosofijos požiūriu. Savaime politinès pareigos Senekai neturi nei teigiamos, nei neigiamos vertės. Apskritai aktyvus politinis gyvenimas gali būti ir geras, ir blogas, nelygu, kas ir kaip elgiasi. Tačiau iš tikrųju politikos pasaulis, Senekos teigimu, yra nešvarus. Čia tyko tiek galimybių igyti ydų, jog kiekvienas, pasirinkęs gyventi dorai, turètų kiek įmanoma vengti politikos. Esama ir kitos priežasties, kodèl Seneka atsiriboja nuo aktyvaus dalyvavimo valstybès gyvenime: pakitę patys apibrèžimai, kas iš tikruju yra valstybė, šalis, tėvynè. Nuo politinės žmonių bendrabūvio santvarkos Seneka gręžiasi prie prigimtinės daiktų santvarkos. Būtent ši, viską apimanti pasaulinè santvarka, varoma lemties, tampa jo tikrąja tẻvyne ir valstybe.

I

n this essay, I would like to discuss

Seneca's views regarding man's ${ }^{1}$ ethical the place of politics and statesmanship nature, his political engagements, and in Seneca's moral philosophy. The text how the two bear one upon the other, is on which I base my understanding of entitled Ad Lucilium epistulae morales (see 
Seneca 1967; 1970; 1962; 1986). The thoughts contained in it are an outstanding example of Roman Stoicism which, as I am soon to indicate, takes for its ideal the life of virtue and wisdom as an existential ground for personal resignation and tranquility in the face of unpredictable fortune. Ad Lucilium epistulae morales has reached us in several versions, among the scholars it remains a matter of dispute which of those versions are more authentic and original and which are not. The epistles were written to a certain Lucilius, supposedly a representative of the Roman emperor in the province of Sicily, but it also stays unresolved among the scholars whether Lucilius was a real person or just an imagined one conceived by Seneca as a literary device.

\section{THINKING AND PRACTICING HUMAN NATURE}

Ad Lucilium epistulae morales consists of one hundred twenty four letters in which Seneca reveals his vision of the nature of man. His moral insights are as profound as delightful is the manner of his discourse. First and foremost Seneca is a philosopher. By philosophy he understands both self-knowledge and a way of life rooted in such knowledge. It is man who knows, it is man who should be known, and it is he should live in accordance with what be knows. Yes, there are countless things besides man, a whole universe, but the maxim of philosophy still is: "search yourself first, and then the world about you" (Seneca 1967: LXV 453).

The principal questions for Seneca as a philosopher are these: What is man? What is his nature? What is his place in the universe? How should he lead his life on earth? And how should he prepare for death and die? Philosophy is attempting to answer these questions, philosophy is not yet wisdom, it is a love of wisdom, it hurries to be where wisdom already is (see Seneca 1970: LXXXVIII 365). Philosophy is a way of life (see Seneca 1967:
VI 27) ${ }^{2}$ in harmony with the essence of things, it is a fundamental disposition of the soul different in kind from all sorts of sophistry. The message of philosophy is expressed by deeds, not by mere words. Philosophy thus entails activity, but it is not the sort of activity which was solicited by Marx a century and a half ago $^{3}$. Seneca exhorts to change the soul, not the world (see ibid.: XXVIII 199), Marx, on the contrary, tries to transform the world without probing the health of human souls. The philosopher is by definition somebody who cares for his soul; hence, philosophy offers wise counsel for those who are concerned with the betterment of their souls.

Moral goodness, virtue, reason, nature - these are human realities which seem to imply each other. Man's good is to follow his nature (see Seneca 1970: LXVI 27), virtue is the state of soul which fulfills human nature, reason is the arbiter of what is good and virtuous and of what is bad and vicious (see ibid.: LXVI $25)$, finally, nature is man's own identity. To be good and virtuous is natural for man. In a way, the saying, a man is good, 
is a tautology, since only inasmuch as a man is good is he a man, and to the degree to which he is evil, he loses his very humanity. Hence, through philosophy we should have discovered who we are, why we were born, and how we ought to live; through philosophy, that is, we should have learned that we are rational beings who can know what is good for them, that we were born in order to fulfill our nature by following it (see Seneca 1967: V 21, XLI 277).

And what is human nature? It is to possess spiritual freedom, peace of mind, and self-mastery vis-à-vis all contingencies of irreversible destiny. Self-mastery is the means whereby a person gains inner freedom and tranquility. Self-mastery characterizes the moral capacity of man to proceed from knowing what is good to pursuing only what is good, while resisting all forms of non-goodness and evil. Human vices have two sources, spiritual and corporeal. To spiritual vices belong vainglory, empty pride, fear of destiny and death, to corporeal vices belong gluttony, drunkenness, debauchery, sexual orgies, and the like.

Let us first turn to spiritual vices. Why are they vices? Because those who give in to them lose freedom, succumb to anxiety, fail to control their feelings and actions. Take, for instance vainglory. Its source is the opinions of others. Those who indulge in vainglory live in the illusion of really having what is ascribed to them from outside. The only picture they have of themselves is what they are thought of by others. They are the slaves of their own public reputation. Yet, neither vainglory nor empty pride reflect the actual state of one's soul. They point to a weak and feeble soul constrained by a noxious dependence on external reality for its identity. Everyone, therefore, who is subject to vainglory, empty pride, and similar vices, is not free, he is a clay shaped and molded by the hands of others, a clay which cannot choose its own form, since its form is always forced upon it from without. Or take those who fall prey to the irredeemable dictates of destiny and who are seized by panic and filled with horror the moment they realize that one day they are going to die. As a result, the souls of such people are possessed by fear, worry, anxiety, dejection, hopelessness, and despair. They cannot die at peace because they are afraid to, nor can they live at peace because they are haunted by a possibility of death at every step of their lives. They are struck between life and death without properly living and without properly dying.

Those who are ruled by corporeal vices find themselves in no lesser trouble. Take, for example, a man who is addicted to riches, all the time he is tortured by a thought that what he has is not enough, and so he continues amassing material goods without a sense of satisfaction. Such a man is insatiable, he always feels he should have spend more money and purchased more things, and is almost driven mad when he notes that the more he has the less it seems to be. For him to have enough is an outright impossibility. Who is to call such a man free, or peaceful, or one who is his own master? If anything, he is the opposite of these noble qualities of human nature. 
He is completely dependent both on what he has and on what he has not, he is filled with the anxiety of how to get more and how not to lose what he already owns, he cannot control his lust for larger possessions.

I mentioned earlier that philosophy for Seneca is a good counsel for those who wish to regain their own nature. What would be Seneca's philosophical advice for those who suffer from the vices just described?

If it is fear of destiny, do not let it surprise you, do not count on unwarranted success, imagine the worst that could happen to you and get ready for it, and nothing unexpected will ever strike you. Each day repeat to yourself: all is mortal according to obscure laws: today may occur all that can occur at any time else (see ibid.: LXIII 437). Draw your strength from your past experiences and accomplishments, for even though destiny can snatch from you what you have now, it can never bereave you of what you have had in the past, nor can it deprive you of the spiritual effect which the past has had on your soul (see Seneca 1962: XCVIII 123-125).

If it is fear of death, do not claim to know more about it than you actually do. Think of death as inseparable from life, and if you desire the first, you should also embrace the other. Dying is a duty for the living (see Seneca 1970: LXXVII 177)! You are young and full of vitality? Then remember that the toll of death pays no heed to chronological order. You are old and sapped of bodily powers? Then remember that you are not so old as to be unable to accept another day of life. Even if death seems to step on your heels, perhaps you await a death sentence or you are in the midst of a heated battle where there is more dead flesh than living, even then do not get with your fears ahead of your death for it can always bypass you, get prepared to meet her, but do not run into her clutches before you have encountered her (see Seneca 1962: XCVIII 123).

If it is addiction to riches or other bodily vices such as gluttony or sexual lust, learn your limits, discover your basic needs, find out what the necessary means are which would grant you a healthy body. Practice moderation and search for bodily comforts in good measure. What is necessary and what is enough should be your goal (see Seneca 1967: II 9), not the variety and amount of pleasure you may obtain - that is foolishness! Let the mind rule over the body, let the body never assert itself over the mind. Care for the body so that every once in a while you might forget that you have one.

One who takes the wise instruction of philosophy to his heart soon will become his own master, the captain of his soul. He will become free. No longer will he be a slave to anything, to circumstances, to necessity, to accident, he will never again allow destiny rise above himself (see ibid.: LI 341). He will find himself at rest, filled with spiritual tranquility, always at peace with himself. Thus, free, peaceful, and self-determined, such a man will have reached his end: he is finally what he should be, he is what he is by nature called to be, a good man and a sage. 


\section{LIVING AND DYING WISELY}

What would Seneca say about the attitude towards life and death characteristic of a sage? I mean the general spirit of his comportment and not the detailed principles of his actions. Life for a sage is not a temporal stretch but a qualitative reality. What matters is not living in itself but living well. The ideal is a good life, while life as such need not be something good (see Seneca 1970: LXX 57; 1962: XCIX 135). Seneca does not discard the reality of time, nor does he deprecate its importance for the living. He only stresses that for a sage time is always subordinate to the quality of life. The completion and perfection of life are not relative to the span of time the sage has spent on earth, what is significant is not how long he has lived, but how well he has lived. There are those who have lived long but "little." A sage, in contrast, may have lived just for a short time but still has lived "much" (Seneca 1970: XLIX 329; 1962: XCIII 7).

This is an attitude proper to a sage: he receives life without love or hatred and patiently bears the lot of mortals (see Seneca 1967: LXV 455). He humbly accepts what the cosmos has decreed for his life, fortunes as well as mishaps, because he understands that all things, which at first glance appear as harmful, help to maintain the universe and determine the necessary and circular movement of the world. Let it please to man, what pleases to the gods (see Seneca 1970: LXXIV 127). Thus, a sage tires not to change what he can - his soul - but is filled with ample resignation and do- cility towards the ineluctable course of world-events chosen by the gods and governed by them.

A sage acknowledges the inevitability of death and thus treats his life as a rehearsal of his death. His attitude is this: suppose, I shall disappear, suppose, nothing is left of man after his death, yet I am calm, even if I walk away into nonbeing (see Seneca 1962: XCIII 9). A sage lives as long as he ought to, not as long as he is able to (see Seneca 1970: LXX 57). If he feels that he has already reached wisdom and goodness and if life is becoming intolerable for him because of physical pain or social insecurity, he may freely choose to commit suicide, since no temporal addition to his life could be an addition to the quality of his life, and why should he undergo unnecessary discomfort? To be sure, it is a shameful thing to flee from death or to flee into death (see Seneca 1962: XCVIII 129), but the sage does not flee from death, he simply walks away: "Live, if you so desire; if not, you may return to the place whence you came" (Seneca 1970: LXX 65). As a matter of fact, nothing more wonderful has been issued by the eternal law of the universe than that it has provided us but with one way to enter life and with so many ways to depart from it (see ibid.: LXX 65). "Hence you can understand that nothing but the will need postpone death" (ibid.: LXX 69). A sage is not afraid of death, nor is he afraid of his ability to take his life, in fact, he cherishes it and when the time is ripe he uses it. ${ }^{4}$ 


\section{POLITICS AND ETHICS}

For the past several pages I have been recounting Seneca's ethical doctrine. But where is politics in all of this? - you may ask. The truth is: politics is almost absent from Seneca's moral philosophy. This is the reason why I gave my essay the title, "Teachings Concerning Apolitical Morals." Well, almost apolitical, because there are a few items which do relate to the sphere of politics, as I am soon to show. Nevertheless, it is truly astounding that a Roman can refuse to acknowledge participation in the affairs of state as a virtue. It is hard, therefore, to reconcile Seneca's understanding of what wisdom and virtuous life are with that of, say, Cicero (cf. Cicero 1929). For Seneca the sage is a reclusive philosopher immersed in ascetic self-perfection, for Cicero the sage is a statesman, one who runs public duties, who lives and dies for the weal of his homeland and his countrymen. For Seneca virtue is a state of an individual soul, for Cicero it is an action directed to a community of citizens. Doubtless, that the ideal of morality seems to be very different for these two Romans, Seneca and Cicero.

Political office as an activity holds for Seneca no intrinsic value, positive or negative. Active political life belongs to the sphere of "indeterminate" actions which can be good or bad depending on who performs them and how (see Seneca 1962: CXVIII 367). To be a consul is neither good, nor bad. It is good when one is a good consul, likewise, it is bad when one is a bad consul. The same applies to such occupations as lectors, mag- istrates, princeps, generals, and so on. Hence, in principle taking part in the affairs of state can be good as it can be evil. But it is so only in principle. In actuality, however, the world of politics, for Seneca, is a dirty business. "[R]iches, titles, power, and everything which is valuable in our opinion," he states, are "worthless" and "deflect us from the right course" (Seneca 1970: LXVIII 49, LXXXI 237). Political activities are fraught with so many dangers, so many ways to contract vice, that everyone, who has chosen to pursue a life of virtue, should shun them as much as possible. Hence Seneca's advice to his friend Lucilius: "retire and conceal yourself in repose" (ibid.: LXVIII 45-47). Of course, what is meant is public activity. And remember, this exhortation is directed to a representative of the emperor in one of the Roman provinces!

Another reason why Seneca distances himself from active participation in the life of the state is his re-definition of what state, country, homeland really are. Seneca no longer views himself as a citizen of Rome. "I am not born for any one corner of the universe," he declares, "this whole world is my country" (Seneca 1967: XXVIII 201). This assertion shows just how well Seneca had appropriated the central tenet of Stoic cosmopolitanism. To call the state the world is not merely to expand its geographical terrain. It is to pass from a political order of human relations to a natural order of things. Yes, the world is an order, but it is an order that is determined by 
the gods, not by men, an order which proceeds without the help of men. The name of this world-order is destiny. It is not fashioned by men; it is more likely that men are fashioned by it. Thus, to speak of taking an active part in the affairs of world-state loses all sense. The only politicians here are the gods. Men are subjects, they must follow the eternal course of world-events, incapable of contributing anything to it except their docile submission. Indeed, the sage does sometimes respect earthly politicians. He esteems them and is grateful to them, whenever these men of power

\section{References}

Cicero Marcus Tullius. 1929. On the Commonwealth. Translated by G. H. Sabine, S. B. Smith. Indianapolis: The Bobbs-Merrill Company, Inc.

Marx Karl. 1973. Theses on Feuerbach, Marx K., Engels F. Selected Works: In Three Volumes, vol. 1: 13-15. Moscow: Progress Publishers.

Seneca. 1962. Ad Lucilium Epistulae Morales, vol. III. Translated by R. M. Gummere. Cambridge (MA), London: Harvard University Press, William Heinemann Ltd.

\section{Endnotes}

1 Throughout the article, I shall adhere to the generic usage of the words 'man' and 'men,' including the masculine personal pronouns referring to them, to signify 'human' and 'humans,' respectively.

2 When Seneca speaks of Socrates, it is not his arguments that he exalts, but the Socratic way itself. secure his "peace and leisure" (Seneca 1970: LXXIII 105), since there is nothing more he needs in his solitary contemplation of virtue.

Still, good politicians seem to be necessary only in the presence of bad ones. The peace of the sage would not have to be defended, if it were not endangered to begin with. The ideal state, therefore, is apolitical, from which political endeavors, bad as well as good, are simply absent, the ideal state, therefore, is natural, for nature is never at war with itself, the world-state requires no parliament to maintain its everlasting peace.

Seneca. 1967. Ad Lucilium Epistulae Morales, vol. I. Translated by R. M. Gummere. Cambridge (MA), London: Harvard University Press, William Heinemann Ltd.

Seneca. 1970. Ad Lucilium Epistulae Morales, vol. II. Translated by R. M. Gummere. Cambridge (MA), London: Harvard University Press, William Heinemann Ltd.

Seneka. 1986. Laiškai Lucilijui. Iš lotynų k. vertė D. Dilytè. Vilnius: Mintis.

3 In his epigrammatic 11th thesis on Feuerbach: "The philosophers have only interpreted the world, in various ways: the point, however, is to change it" (Marx 1973: 15).

4 Recall the manner in which Seneca himself died! 